$\mathbb{A}$ $\mathbb{R}$
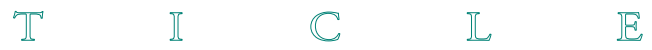

Joâo Manuel Oliveira de Carvalho

Universidade de Lisboa

\title{
PORTUGUESE DIPLOMATIC CORRESPONDENCE AND INFORMATION CHANNELS DURING THE WAR OF THE SPANISH SUCCESSION
}

\begin{abstract}
During the War of the Spanish Succession, Portugal joined the Grand Alliance in 1703. It made it involved, from that year on, in the conflict that included most of the major European Powers in a dispute for the Spanish throne, which, ultimately, represented a contest for dominance in Europe. Under these circumstances, several diplomats were in charge of representing Portugal at the main European courts, protecting its interests and communicating regularly with the court of Lisbon.

This paper addresses an understudied set of the correspondence written in this period by Francisco de Sousa Pacheco, the Portuguese envoy to The Hague, to João de Almeida Portugal, Portuguese ambassador to the court of Archduke Charles of Habsburg, one of the pretenders to the Spanish throne, in Barcelona. The main objective of this article is to study the information network established in Europe, mainly in the Grand Alliance side, and the different routes letters followed from The Hague to Barcelona, either using the existing postal system or known intermediaries. Letters were not the only means diplomats had to convey information to their addressees. They also sent other sources of information, like periodicals, accounts of events and pieces of information gathered from different sources, including propaganda in its various forms. It also analyses the developments of the war, the structure and evolution of these letters and the struggle of these diplomats with the other states to make sure their commitments to send military and financial support to the troops were fulfilled. He also wrote about the espionage within the various courts, and the interception diplomatic letters suffered from the opposite side.

Ultimately, we'll see the efforts of these ambassadors as a means for Portugal to gain recognition within Europe, although it ended up with an increasing dependency on foreign states support.
\end{abstract}


Keywords: Diplomatic correspondence, War of the Spanish Succession, information typology, information sources, mailing routes, intermediaries

\section{INTRODUCTION}

Portugal joined the Grand Alliance in 1703 to take part in the War of the Spanish Succession, despite the various economic and military challenges it faced. Among others, this alliance comprised England, the Holy Roman Empire and the United Provinces against France and Spain in a dispute over the throne of the Monarchy of Spain.

In this context, the Portuguese envoy to The Hague, Francisco de Sousa Pacheco, wrote an abundant correspondence to the Portuguese ambassador to Barcelona, João de Almeida Portugal, Second Count of Assumar and one of the few European representatives at the Archduke Charles' court. The latter was a member of the House of Habsburg and one of the pretenders to the throne of Spain. The archduke was supported by the Grand Alliance, in opposition to the other claimant, Louis XIV's grandson Philip, Duke of Anjou, from the House of Bourbon. The letters under scrutiny in this article dated from the period between 10 August 1705, the point at which the Count of Assumar travelled with Charles III to Catalonia, and 13 September 1709, the last letter Sousa Pacheco wrote, as he would pass away soon after. ${ }^{1}$

Regularly and with very few exceptions, Francisco de Sousa Pacheco wrote one letter per week to João de Almeida Portugal. They illustrate the complexity of the duties assigned to him - the transmission of issues that could interest Portugal, including the course of the War of the Spanish Succession, as well as political news and reports of his diplomatic activities. ${ }^{2}$ This correspondence was also an important source of information for Archduke Charles's court, which was highly dependent on outside channels to provide him with news of the military support he much needed and the course of the war in Europe, among other information. This correspondence was also vital for Portugal,

1 João Carvalho, 'Diplomacia, Guerra y Comunicación. La correspondencia de Francisco de Sousa Pacheco, enviado portugués en La Haya (1703-1709)', unpublished master's thesis, Complutense University of Madrid, 2016, p. 43.

${ }^{2}$ Ibid., p. 44. 
helping it to bolster its long-awaited international recognition as a new independent state. Even after signing the Treaty of 1668 which put an end to the Iberian Union, Portugal strove hard for this recognition. It must be noted that Portugal was badly prepared for the War of the Spanish Succession. Inefficient military organization and recruitment, as well as chronic financial difficulties, were the main reasons why it relied heavily on foreign assistance. ${ }^{3}$

The Hague was one of the largest European information centres, which made it an ideal environment for Francisco de Sousa Pacheco to develop his information sources. The Hague attracted authors who published books, journals, pamphlets, maps and images. These circulated among society in the Dutch city and, by extension, around Europe. They reveal a high level of literacy, uncommon at that time.

This article will examine how these Portuguese diplomats acted to enhance Portugal's value as a strategical kingdom from where to launch military campaigns against Bourbon Spain. Portuguese ports could serve as stepping stones for naval expeditions to the Mediterranean and, in turn, attract increased commerce. It will also strive to reconstruct the information networks the Portuguese envoy in The Hague used, as well as to examine the structure of the letters, the various sources of information and the courier routes.

\section{STRUCTURE OF THE CORRESPONDENCE}

The letters from the Count of Assumar were one of the main sources of information both for Sousa Pacheco and for the States General, the legislative and representative body of the United Provinces. This correspondence helps us to better understand the course of the war from Charles III's side, which was of great interest to the members of the Grand Alliance. These letters addressed numerous subjects and issues with which Sousa Pacheco was expected to deal, such as the course of the war, political stances of the European courts and requests for financial and military support.

${ }^{3}$ Pedro Cardim, 'Portugal en la guerra por la sucesión de la Monarquía española', in La Guerra de Sucesión en España y la batalla de Almansa: Europa en la encrucijada, coord. by Francisco García González (Madrid: Sílex, 2009), pp. 231-85 (p. 251). 
Given the importance of this channel of communication between The Hague and Barcelona, it was necessary in 1705 to increase the frequency of this correspondence and to expedite the delivery of these letters to the Count of Assumar, who had been appointed ambassador extraordinary to the court of Archduke Charles, whom the Grand Alliance recognised as Charles III of Spain. ${ }^{4}$ An Anglo-Dutch fleet carrying the archduke and the Portuguese ambassador was on its way to liberate Barcelona from a Bourbon siege to enable the opening of another front in the Iberian theatre. ${ }^{5}$ During this time, the Count of Assumar would promote the notion of marrying Prince John of Braganza to the archduchess Maria Ana. This plan was intended to strengthen the relations between the courts of Lisbon and Vienna, and details of the scheme were actively discussed in Portugal. ${ }^{6}$ Meanwhile, in northern Italy, the conflict was proving fierce with a series of battles, such as the clash at Cassano. But, after successfully raising the French siege of Turin, the Alliance was able to establish a victory in that theatre by expelling the French and Spanish forces and allowing Victor Amadeus II, the duke of Savoy, to fulfil his wish of becoming independent from his French neighbours.

In 1706, Francisco de Sousa Pacheco was highly concerned about the reliability of the mailing system, repeatedly asking the Count of Assumar to confirm whether the letters were arriving quickly and safely. In fact, it seems Sousa Pacheco overestimated the dependability of the system required to transport letters from The Hague to Barcelona. In addition, he was surprised by the Count of Assumar's lack of motivation to maintain a continuous flow of information, which would result in disapproval from the court of Lisbon. ${ }^{7}$

Meanwhile, the Allies were succeeding in their war efforts in the Iberian Peninsula. Barcelona was freed from another siege and Madrid was occupied by the allied troops led by António Luis de Sousa, Second

${ }^{4} \mathrm{He}$ already performed these services in Lisbon, when the archduke was at Belém in 1704. Diario Bellico. La Guerra de Sucesión en España, de Frei Domingos da Conceição, ed. by Joaquim Albareda, Virginia León Sanz (Alicante: Universidad de Alicante, 2013), p. 74.

${ }^{5}$ Cardim, p. 263.

${ }^{6}$ Diario Bellico, pp. $74-5$.

${ }^{7}$ Madrid, Biblioteca Nacional de España (hereafter cited as: BNE), MS 8980, fol. 75. 
Marquis of Minas. ${ }^{8}$ However, due to the slow progress of the archduke towards Madrid and poor strategic decisions, the second half of 1706 saw much of the allied progress in the Peninsula halted by the Bourbon forces. The allied army had to retreat to Catalonia and Valencia, the latter of which was rich in resources. ${ }^{9}$

A war council was called in Valencia in October 1706 and the Count of Assumar strongly advocated the creation of a Committee to co-ordinate military operations since the army was suffering from poor organization and preparation. ${ }^{10}$ The recurrent lack of resources, and poor coordination between the different generals in command, as well as the abuses forced on the population, stimulated significant tensions and confrontations between the soldiers and peasants, not only in this year but throughout the course of the conflict. ${ }^{11}$

Up to 1707 , the correspondence of the Portuguese envoy in The Hague followed a conventional pattern. It prioritised the news according with the importance of each theatre of operations. His epistles also touched upon other topics, such as the correct delivery of the letters, the misinformation spread by the French and some peripheral military operations. During 1707, however, his letters began to target a complex and more restrictive array of topics with lower strategical value. He addressed such issues as the route the letters should follow, their irregularity, and the information available in The Hague in relation to the war situation in the Iberian Peninsula.

The situation for the Portuguese changed after the severe defeat inflicted by Franco-Spanish troops at the Battle of Almansa. ${ }^{12}$ The political and military influence of the court of Lisbon diminished radically. The pretended independence of the Portuguese army in leading the troops now changed to a situation whereby English officers commanded Portuguese troops in the field and provided the necessary

${ }^{8}$ BNE, MS 8980, fols 33-102; Cardim, p. 252.

${ }^{9}$ Henry Kamen, The War of the Succession in Spain, 1700-1715 (Bloomington: Weidenfeld and Nicolson, 1969), pp. 17-18.

${ }^{10}$ Diario Bellico, p. 58; Cardim, p. 256.

11 Diario Bellico, p. 28.

12 Joaquim Albareda, La Guerra de Sucesión en España (1700-1714) (Barcelona: Crítica, 2010), pp. 223-26; Kamen, pp. 18-19. 
supplies. ${ }^{13}$ Nevertheless, after Almansa, approximately one-third of the overall allied army assembled in Catalonia was still comprised of Portuguese soldiers. ${ }^{14}$ For this reason, Francisco de Sousa Pacheco increased his efforts in asking for further financial and military support from the Grand Alliance for Portugal. The Portuguese also had to maintain a stout defence against the raids the Spanish were imposing on their borders, in addition to the burden of paying their troops in Catalonia.

Moreover, painful gout which Francisco de Sousa Pacheco suffered forced him to limit the content of his letters in 1709. He increased the number of gazettes, pamphlets and other types of newspapers included in those letters, without the previous analysis of information he used to prepare. ${ }^{15}$ Because Flanders was now the principal theatre of war for both the Allies and France, events and developments there became the main topic of his letters, followed by the situation in the Iberian Peninsula. The structure of his letters became more confused, and increasingly failed to follow any fixed pattern - instead they were confined to the communication of any news he got to know. Francisco de Sousa Pacheco would also continue to request the support which Portugal and Catalonia genuinely needed, though without any great success. ${ }^{16}$ It would indirectly cause the inability of the Portuguese army to secure a route of reinforcements and supplies between Portugal and Madrid when the Allies retook this city the following year. ${ }^{17}$

Meanwhile, Louis XIV decided to withdraw most of his troops from Spain, allowing, on the one hand, the growth of anti-French sentiments in the court of Madrid, and on the other, the chance for the Allies to launch an offensive, commanded by the imperial general Guido von Starhemberg and strengthened by reinforcements from the Empire. The Allies reclaimed Aragon and made further progress until Louis XIV sent assistance to the Spanish. The Bourbons were better equipped to face

${ }_{13}$ Diario Bellico, pp. 62-64.

${ }^{14}$ Cardim, p. 275.

${ }^{15}$ Carvalho, p. 68.

16 These efforts would intensify after receiving the news of the defeat suffered on the Caia River on 7 May 1709, which resulted in considerable losses for the English and Portuguese troops; Kamen, p. 20.

${ }^{17}$ Cardim, pp. 279-80. 
multiple theatres of operations by comparison to the Portuguese, who were generally kept on the defensive. ${ }^{18}$ However, Pacheco's subsequent letters would focus on the peace negotiations now underway between the French and the Dutch which concluded in a proposal for peace, known as the Preliminaries of The Hague. Francisco de Sousa Pacheco's main contribution to these peace talks was his frequent emphasis on the need to exchange prisoners of war, especially Portuguese. ${ }^{19}$ Moreover, he would monitor the progress of these peace negotiations with both the representatives of the States General and the Duke of Marlborough, speculating that peace would not ensue unless Archduke Charles regained the entirety of the Monarchy of Spain. This seemed improbable, due to the other powers' intentions. ${ }^{20}$ Ultimately, this attempt for peace did not succeed, and he did not live long enough to know of its failure.

\section{SOURCES OF INFORMATION}

\section{Gazettes}

Besides direct contacts with other people, Francisco de Sousa Pacheco required a wide range of information media, such as gazettes, to get access to all the news he wrote about. In these gazettes, news, rumours and war reports were collected and published in one "final" paper, ${ }^{21}$ which was printed weekly and read by diplomats regularly. Not only did these gazettes cover any news concerning the War of the Spanish Succession and their participants, but they also provided news on the situation in the Papal States and Naples, and the war between the Swedish Empire, Russia and Poland. ${ }^{22}$ Pacheco also had regular access to the gazettes from France, mostly from Paris. It was one of the most advanced gazettes in Europe, with detail to a fault. But Sousa Pacheco and the rest of the Allies had to be very careful about possible misinformation (as it was

18 Kamen, pp. 20-22.

${ }^{19} \mathrm{He}$ was sent a list of those prisoners from which he could identify who should be freed first; BNE, MS 8980, fols 268v-69.

20 BNE, MS 8980, fols 281-82v.

${ }^{21}$ María Rosa Cal Martínez, 'La Gaceta de Madrid y la Guerra de Sucesión', Cuadernos Dieciochistas, 3 (2002), 33-56 (pp. 35-36).

22 BNE, MS 8980, fols 132-135v. 
the gazette from the enemy side), since this could cause confusion and mistakes when making political, diplomatic and military decisions. At the very least, the erroneous information could cause decisions to be delayed. Nevertheless, the French gazette proved to be another crucial source of information regarding the situation in the Iberian Peninsula.

Francisco de Sousa Pacheco regularly read most of the gazettes published in European cities, especially those produced in the towns of the United Provinces, such as Amsterdam and Rotterdam, as well as those that came from the north of Italy, Flanders, Paris, Vienna, Frankfurt, Naples and London. ${ }^{23} \mathrm{He}$ often sent copies of these to Lisbon ${ }^{24}$ and, of course, to the Count of Assumar - unfortunately, these often arrived late, thus diminishing their usefulness. However, he needed to read them first so he could transmit information about the European situation to the Count and also to the court of Lisbon. Francisco de Sousa Pacheco would eventually stop sending information about Italy to the Count of Assumar, because of the end of the conflict in that theatre. ${ }^{25}$

It has been noted that gazettes covered a great variety of subjects, and their weekly publishing frequency allowed them to spread a reasonable amount of fresh news in every issue. As previously stated, Sousa Pacheco tended to send his letters regularly once every week, which leaves us to conclude that there was a correlation between the writing of the letters and the publishing of the gazettes. A clear case of this relation is a letter Sousa Pacheco wrote to the Count of Assumar on Friday, 22 July 1707. It addressed issues that were published that same day in a gazette from Amsterdam, and it is clear those were not simple extractions of content; they had been subjected to analysis, confirmation and reasoning. ${ }^{26}$

23 Ibid., fols 36-37v; fols 133-134v.

24 The ones published in the Portuguese capital were submitted to the censorship and interests of the king and his court, who received most of its European information from foreign gazettes and other material sent by his diplomats, previously translated into Portuguese. André Belo, As Gazetas e os Livros. A Gazeta de Lisboa e a Vulgarização do Impresso em Portugal (1715-1760) (Lisboa: Instituto de Ciências Sociais, 2001), p. 43.

${ }^{25} \mathrm{He}$ would also guess that the information about that region would arrive much sooner and updated directly from Genoa than from The Hague, a route which took much longer due to either the distance by sea or the perils by land in a continent at war. BNE, MS 8980, fols 26-27v.

26 Carvalho, p. 48. 


\section{Account of events}

Accounts of events and military reports were connected through their subject: the course of the war. They reported on the occurrence of a battle or the progress of an important military campaign. Sometimes the information given in these reports was unreliable due to the biased view of the facts or because they were usually finished on short notice and sent as fast as possible. Still, nonetheless, these incomplete sources remained important due to their initial first-hand perceptions. ${ }^{27}$ They were, however, submitted to state censorship as no criticism of the government was allowed. ${ }^{28}$

Military expeditions were joined by another kind of war: that of propaganda. Its objective was the deliberate spreading of ideas, rumours or incomplete information about the developments of the war to damage the opposing side and thus win more supporters. The most significant quantity of Portuguese accounts of events in this period was published in 1704 when the expedition launched by Peter II of Portugal escorted Archduke Charles into Castile from Portugal. What was supposed to be a glorious expedition for the Portuguese king ended instead in a humiliating retreat, even before the archduke could cross the border. ${ }^{29}$ Throughout the rest of the War of the Spanish Succession, only the years 1706 and 1710 saw similar quantities of accounts of events published. These years coincided with the two allied occupations of Madrid - during the unfavourable situation between those years the allied side published fewer reports of events in Spain. Some of these accounts were anonymous, but we know the names of who published the others: António Pedrozo Galrão published 44 per cent of the accounts

${ }^{27}$ Ramón Cózar Gutiérrez, 'La participación portuguesa en la Guerra de Sucesión española a través de las Relaciones de Sucesos de su Biblioteca Nacional', in La Guerra de Sucesión Española y la opinión pública hispano-británica, ed. by Pedro Losa Serrano (Madrid: Sílex, 2014), pp. 133-70 (pp. 137-39).

${ }^{28}$ Henry Ettinghausen, 'Politics and the press in Spain', in The Politics of Information in Early Modern Europe, ed. by Brendan Dooley and Sabrina A. Baron (London: Routledge, 2011), pp. 199-215 (p. 202).

${ }^{29}$ Philip V had launched his own offensive on Portuguese borders and an effective campaign in the territory of Portugal, against which the allied forces were unable to defend; Cardim, pp. 254-57. 
during that period, while the rest were printed by Miguel Manescal, Valentim da Costa Deslandes and Bernardo da Costa. ${ }^{30}$

The correspondence of Sousa Pacheco to the Count of Assumar mentioned the chronicles of events and also included some of them. Some examples include Lettre du duc de Marlborough á leurs Hautes Puissances, Touchant sa marche pour aller attaquer l'Ennemy, printed in Wavre on 19 August 1705, Lettre du Prince Eugene, from Treviglio on 17 August 1705, and Relation de l'affaire entre Treviglio et Cassano le 16 d'Aoust 1705, printed in The Hague in $1705 .{ }^{31}$ These testify to the routine Sousa Pacheco had of sending printed letters and other documents to the Count of Assumar about other war theatres, for instance the previously-mentioned example of the Battle of Cassano in Italy. This also worked both ways, as the Count of Assumar would send accounts of events to Sousa Pacheco too, for example, a description of the Battle of Almansa. The latter would forward these accounts to the Secretary of State, Diogo de Mendonça Corte Real, assuming it to be highly precise. Later on, Corte Real sent the account of the battle of the river Caia, a defeat the Portuguese suffered on 7 May 1709, to Sousa Pacheco who, in turn, transmitted it to the Count of Assumar, appended to a copy, in French, of the Preliminaries of The Hague, dated 28 May $1709 .^{32}$ This illustrates how smoothly the information network between The Hague, Lisbon and Catalonia could work.

\section{Diaries}

Lastly, it is necessary to mention several documents related to the Spanish theatre. The Second Count of Assumar was the author of a series of diaries relating to his travels and activities while accompanying the court of the proclaimed Charles III. One was written in 1705 and entitled Diário da viagem que fez de Lisboa a Barcelona, in which he documents his voyage from Lisbon to Catalonia aboard a large Anglo-Dutch fleet. ${ }^{33}$

${ }^{30}$ Cózar Gutiérrez, pp. 137-40.

${ }^{31}$ BNE, MS 8980, fols 6-9.

32 Ibid., fol. 132; ibid., fol. 317.

33 The Count of Assumar had sent the original, or a copy, to Luis da Cunha, Portuguese ambassador to London, who after reading it, passed it to Francisco 
Following that, he wrote Continuação do diário e de tudo que vai sucedendo nesta expedição de Espanha e das mais partes da dita Monarquia, which is a narrative from October 1706 to December 1707. We may note here his involvement with the court of Charles III when it was based in Valencia and then in Barcelona, before and after the battle of Almansa in April 1707. The Count of Assumar sent a report about the battle to Sousa Pacheco, who praised it for its detail and suggested its possible use as a basis for devising the future strategy. ${ }^{34}$ After a period with no records of Assumar's writings, he produced Carta e Diário escrito pelo Conde de Assumar, embaixador extraordinário a El Rey D. Joáo o 5º de tudo o que se passou enquanto acompanhou aquelle Principe a sua entrada em Madrid, retirada para Aragão e mais sucessos das tropas desde Maio de 1710 até Fevereiro de 1711. As can be seen, he described the (initially successful) campaign of 1710 , ending with the defeats of the Allies in Brihuega and Villaviciosa (de Tajuña), both in December of that year. ${ }^{35}$ This attempt to document the situation may be considered in different lights, one being its usage as a vehicle to record his political and diplomatic activities in the court to maintain a good deal of influence within it. While the Almansa disaster was mostly blamed on the Portuguese and the Count of Assumar suffered a severe blow to his power with Archduke Charles and his court, he continued to fight fiercely for Portugal's interest in that foreign court.

The other case was the Diário Bellico, written by Fray Domingos da Conceição, who travelled with the Portuguese troops throughout the Peninsula, during most of the conflict in Spain. Although his journal

de Sousa Pacheco around September 1705. We may assume that after the fleet had arrived at Barcelona, this diary came to London probably through an English courier boat; BNE, MS 8980, fol. 11.

${ }^{34}$ The Count of Assumar did send a report about the battle to Sousa Pacheco, who praised it for its detail and the possibility for serving as a base for the next strategic actions; BNE, MS 8980, fol. 132.

35 David Martín Marcos, 'A embaixada de D. João de Almeida Portugal, 2º conde de Assumar, na corte do arquiduque Carlos: Notas diarísticas, percepçóes e identidade', in Repensar a identidade: O mundo ibérico nas margens da crise da consciência europeia, org. by David Martín Marcos, José Maria Inurritegui, and Pedro Cardim (Lisbon: Centro de História d'Aquém e d'Alem Mar, Faculdade de Ciências Sociais e Humanas, Universidade Nova de Lisboa, 2015), pp. 263-84 (pp. 266-68). 
pertains more to the military and social aspects of the war, as well as the history, details and fortifications of cities and towns, it is an essential source for the war in Spain. It is highly detailed and the author attempted to convey as much information as possible concerning the Portuguese engagement as part of the allied armies against the Bourbon forces of Philip V. ${ }^{36}$

\section{Private contacts and correspondence}

Personal contacts were also useful for gaining primary information and knowledge about the court's politics and the secrets of other parties. At the most elevated level, Francisco de Sousa Pacheco often informally met Holland's Great Pensionary Anthonie Heinsius and John Churchill, Duke of Marlborough and chief commander of the allied army, in his residence near the Binnenhof, the political centre of The Hague. They would discuss the course of the war, the political ambitions of each state, and private gossip. Without much success, Sousa Pacheco also used these meetings to request the aid Portugal and Catalonia needed, especially after the failure at Almansa. ${ }^{37}$ The Duke of Marlborough appeared unlikely to send any military help to the Spanish theatre, where allied objectives were floundering. Still, he promised Sousa Pacheco he would send troops if the existing allied forces could manage to turn the situation around. ${ }^{38}$

Sousa Pacheco regularly received letters from Lisbon, mostly from the secretaries of state. The exchange of letters between politicians, administrative officials and diplomats were essential to maintain knowledge of the political, military and economic situation of the Portuguese monarchy. Diplomats were instructed to use letters as a way to transmit information and to write frequently. They should classify and select the subjects which they would talk about in the letter, as they knew that the information being covered in the said letters was politically sensitive.

${ }^{36}$ Can be fully consulted in Diario Bellico, Diario Bellico. La Guerra de Sucesión en España, de Frei Domingos da Conceição (Alicante: Universidad de Alicante, 2013); Martín Marcos, pp. 278-79.

${ }^{37}$ Carvalho, p. 46.

${ }^{38}$ BNE, MS 8980, fol. 258. 
In these epistles, styles of address were established based upon the personal relationship between the correspondents. ${ }^{39}$ In this regard, the Secretary of State would often write to Sousa Pacheco with specific instructions to follow and with information concerning the situation in Portugal. However, their correspondence was not especially frequent, mainly due to the long journey between Lisbon and The Hague. In particular, after the defeat of Portugal and the Allies at Almansa in 1707, he was ordered to focus on obtaining economic and military support from the Dutch, at a time when Portugal had to adapt from a victorious offensive expedition to the challenges accompanying a defensive stance against the Spanish raids and expeditions in its territory.

The Count of Assumar's letters to Sousa Pacheco covered the situation of the Portuguese in the Archduke Charles' court in Barcelona, as well as political and military actions in Catalonia. The Count's letters tended to follow the same routes Sousa Pacheco employed for his letters in the opposite direction, complete with the same insecurity and slowness. However, because the Count's frequency of letter-writing was much lower, his correspondence arrived at The Hague more outdated than those from Sousa Pacheco to Barcelona. Meanwhile, just as Sousa Pacheco was doing, Assumar regularly sent letters requesting Dutch financial and military help for Catalonia. Simultaneously, to compensate for his worsened position after Almansa, he began to communicate directly with high-ranking imperial politicians with the same purpose in mind. After the Italian theatre was secured, the Holy Roman Empire could (theoretically at least) afford to dedicate resources to the war in Iberia. After opening this channel of communication, the Count of Assumar devoted more efforts to corresponding with parties from the Empire who were supporting the Archduke's cause, rather than with the Portuguese court or Sousa Pacheco. For this reason, he was criticised by both for his laxness. He also communicated with his counterpart in London, D. Luis da Cunha, who was more successful in requesting support from the British government for Portugal. The information about how the

${ }^{39}$ Pedro Cardim, “"Nem tudo se pode escrever”. Correspondencia diplomática e información "política" en Portugal durante el siglo XVII', Cuadernos de Historia Moderna, 4 (2005), 95-128 (pp. 99-102). 
English were responding to the requests for support was one of the main subjects of their correspondence. ${ }^{40}$

It is also important to mention that Sousa Pacheco accommodated Fernão Teles da Silva, Third Count of Vilar Maior and Second Marquis of Alegrete, briefly between December 1707 and early 1708. This ambassador was on his way to Vienna to ask, in the name of King John V of Portugal, for the hand of the archduchess Maria Anna of Austria, daughter of the late Leopold I and the sister of the current emperor Joseph I. While he was in the imperial capital, he corresponded with Sousa Pacheco when necessary, communicating, for example, the positive news that General Guido von Starhemberg would depart for Catalonia in mid-March 1708. Later, Sousa Pacheco would accommodate the soon-to-be-proclaimed Queen of Portugal, Maria Anna, when waiting for the ships which would carry her from Rotterdam to Portsmouth and then to Lisbon to formalize the marriage. ${ }^{41}$

The Dutch ambassador to Lisbon, Francis Schonenberg, was also a significant figure in Dutch-Portuguese diplomacy in the early stages of the war. Although most of the praise for securing Portugal's accession to the Grand Alliance went to John Methuen and his son Paul, Schonenberg was also considerably influential during the negotiations. Additionally, he was at odds with Methuen due to his influence in the Lisbon court and struggled to secure commercial benefits for the Dutch. After the treaties were signed, he pleaded with the States General to be dispatched as Dutch ambassador to Charles III's court. Possibly because Charles III was forced to abandon Madrid in August 1706, Schonenberg stayed in Lisbon until his death on 13 March 1717.42 Throughout his stay in the Portuguese capital, he corresponded with the States

${ }^{40}$ Carvalho, p. 57.

${ }^{41}$ Isabel Cluny, 'A Casa de Vilar Maior/Alegrete e as alianças matrimoniais da dinastia de Bragança', in Casamentos da Familia Real Portuguesa. Diplomacia e cerimonial, vol. 2, coord. by Ana Maria Rodrigues, Manuela Santos Silva, and Ana Leal de Faria (Lisbon: Circulo de Leitores, 2017), pp. 49-78 (p. 54); BNE, MS 8980, fol. 179; ibid., fol. 225.

42 Alan David Francis, The Methuens and Portugal, 1691-1708 (Cambridge: Cambridge University Press, 1966), pp. 115, 120; Otto Schutte, Repertorium der Nederlandse vertegenwoordigers, residerende in het buitenland: 1584-1810 (The Hague: Martinus Nijhoff, 1983), p. 393. 
General over the matters he negotiated and the political situation of the Portuguese court.

Lastly, Sousa Pacheco was regularly in contact with Francisco Bernardo de Quirós, a diplomat sent to The Hague under Archduke Charles's orders to establish the Austrian claimant's own diplomatic representation in the allied European courts. He was a well-known and experienced Spanish diplomat who attended the peace congress of Ryswick in 1697 that put an end to the Nine Years' War between France and the Grand Alliance. He joined Sousa Pacheco in his efforts to ask for reinforcements and economic support for his master's cause in Catalonia. ${ }^{43}$ He was also ordered to create a committee in Flanders, over which he would serve as the president. ${ }^{44}$ Due to his efforts, it was possible to send the imperial general Guido von Starhemberg and reinforcements to Catalonia to lead the allied armies against Philip V and his forces. Quirós's intended purpose was to urge the Emperor to send Prince Eugene, who was one of the most distinguished and capable imperial commanders, to Catalonia to help the allied army stationed there to fight the French. However, Prince Eugene was deemed crucial to the war effort in Europe, which was why Bernardo de Quirós saw his request denied. ${ }^{45}$

\section{COURIER SERVICES AND INTERFERENCE}

\section{Postal routes}

Francisco de Sousa Pacheco was constantly worried about the transportation of his letters. There were two ways for this correspondence to travel. By land, it was a shorter but risky journey. The letters would be sent from The Hague and transported through the Holy Roman Empire to Vienna. From there they would be sent to Genoa, so they could be put on boats and get to their final destination: Barcelona. ${ }^{46}$ The first time Genoa served as a connection point for the letters sent by Francisco de Sousa Pacheco was on 5 January 1706. This city was his link between

${ }^{43}$ BNE, MS 8980, fols 168-68v.

${ }^{44}$ Albareda, p. 198; BNE, MS 8980, fol. 160.

45 BNE, MS 8980, fol. 162.

46 Ibid., fols 31-32. 
Catalonia and the rest of Europe from then on until the end of the war, with correspondence from Barcelona mainly going either to Vienna or to The Hague. ${ }^{47}$ Genoa was also an important source of information about the military in Italy, which made it a crucial harbour for the Count of Assumar. Sousa Pacheco suggested to the Count of Assumar to use Genoa as the main centre of communication with the European courts, as this route was subject to less interference than the sending of letters around the Iberian Peninsula and through the Atlantic Ocean. ${ }^{48}$

The other option was to send letters by ship, and this was done more frequently, even though delivery took longer. The correspondence was sent by ship from The Hague, sometimes with a stopover in London, and arrived in Lisbon. From there, it would pass along the Algarve coast and, after crossing the Strait of Gibraltar, would travel north-east to reach Barcelona finally. ${ }^{49}$ The second part of the trip was secured by packet boats which travelled between Lisbon and Faro, and then to Alicante and Valencia. ${ }^{50}$ Apart from that, there was a general feeling that the Allies had newly-organised postal service on the Iberian Peninsula. Sousa Pacheco questioned the security of this sea journey, except when the mail was transported by Dutch packet boats or when there was an English fleet escorting the ship after the stopover in London. ${ }^{51}$ Nevertheless, this escort was somewhat unreliable because it seldom materialised due to the lack of regular departure dates.

There were few available alternatives. First, the duration of the journey between The Hague and Barcelona was considerable, and most of the news was considerably out of date at the time of the letter's arrival. For instance, Francisco de Sousa Pacheco confessed in 1707 to have instead relied on the French gazetteers to get information about the situation

${ }^{47}$ Ibid., fols 33-34v.

${ }^{48}$ BNE, MS 8980, fol. 11; ibid., fols 43-44v.

49 Ibid., fol. 47.

${ }^{50}$ Ibid., fol. 103. However, after these cities were taken by Bourbon forces in December 1708 and May 1707 respectively, the allied courier ships had to be careful not to be captured by the enemy. Nonetheless, in 1708, the English had taken Port Mahon which could have also served as a safe port in the Mediterranean for the allied forces and their couriers.

51 BNE, MS 8980, fol. 26. 
in the Iberian Peninsula. On the other hand, as seen in a letter dated 6 July 1708, the Count of Assumar caused Sousa Pacheco some alarm by stating that he hadn't received any correspondence for months. ${ }^{52}$ In that year in particular, their exchange of correspondence suffered excessive delays.

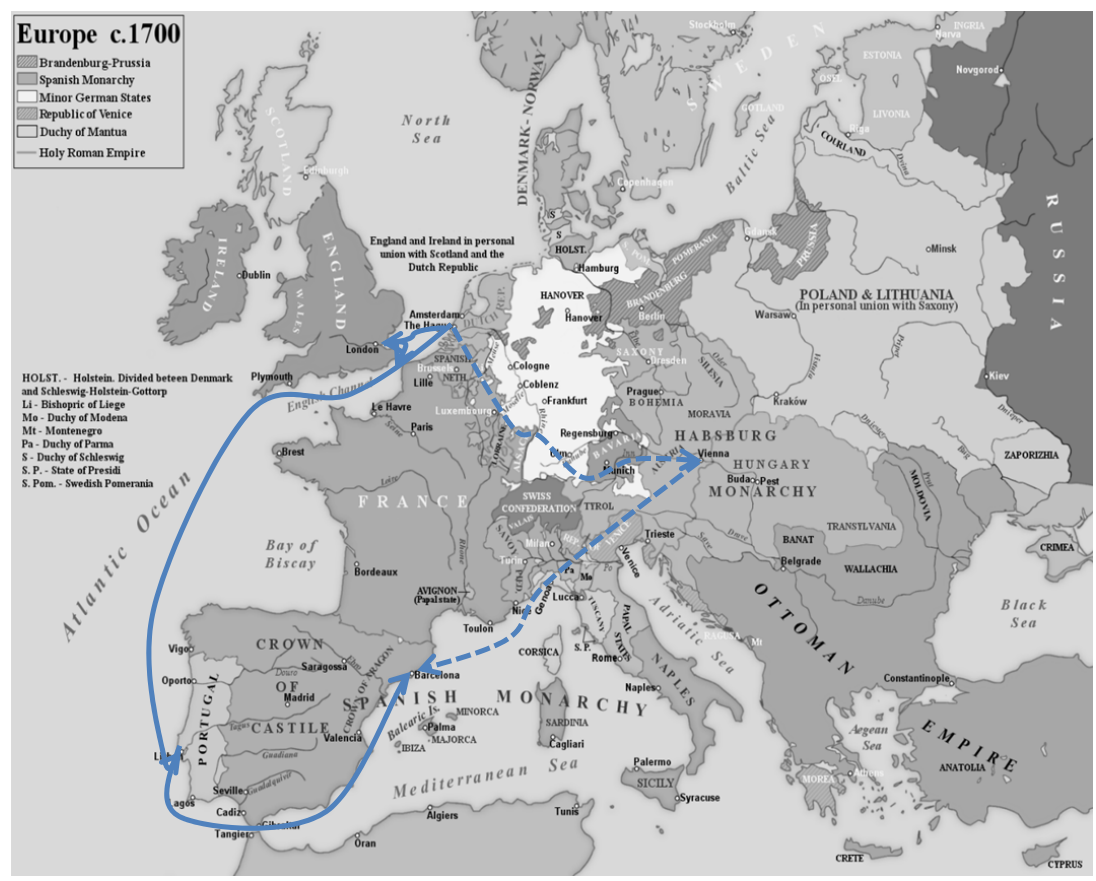

Fig. 1. Map of Europe showing the postal routes from The Hague to Barcelona

Source: https://upload.wikimedia.org/wikipedia/commons/2/23/Europe_c._1700.png. Author Rebel Redcoat. Adapted and modified so it would show the routes of the letters using the information available above.

While the Portuguese ambassador to The Hague suspected possible mail interceptions, he ultimately blamed the situation on the lack of mail organization in Spain and the impossibility of predicting sea conditions that could delay the delivery of the correspondence. The time letters took to be transported from The Hague to Barcelona varied

${ }^{52}$ Ibid., fol. 130, 200. 
from at least one month to approximately five months (like the one dated 18 January 1709). ${ }^{53}$

\section{Intermediaries}

Postal services, either regular or special, brought news to the cities, where people could disseminate it further in their letters. At the same time, editors would publish that information with the possibility of it being re-published in another place, after translation. ${ }^{54}$ Besides using the established postal services, both Sousa Pacheco and the Count of Assumar used other people as intermediaries or couriers to take their letters to their correspondent. During 1706, João Francisco Rossety and the Count of Goes performed that task for the two ambassadors. In 1707, the Count of Falay and the Baron of Wintersfelt helped Assumar to get his letters to The Hague, while Francisco Bernardo de Quirós did the same from the end of 1707 until his death in January 1709. In 1708, the Count of Lecherena, Manuel Coelho de Fonseca, who was a sergeant major under the Habsburg archduke, and the Brigadier Oede ensured that some of the letters were also delivered. And, finally, in 1709, Lieutenant Colonel Kien also arranged for some letters to travel between The Hague and Barcelona. Most of these people were officers in the imperial army and served the archduke's court in Barcelona. Hence, most of them were able to communicate to Sousa Pacheco details of events at the court, in the Spanish theatre of war and other relevant information in more detail. ${ }^{55}$ On 1 August 1709, Sousa Pacheco wrote that carriage drivers of Spa, a city on the eastern border of the Low Countries east border, were in charge of the mail to Vienna. ${ }^{56}$ Therefore, he was guaranteed to receive various kinds of information both through the letters of his correspondent and from the porter of those letters.

Francisco de Sousa Pacheco was himself an intermediary. As already mentioned, he would send gazettes, pamphlets, rumours and account of

${ }^{53}$ Ibid., fols 256-57v.

${ }^{54}$ Ettinghausen, p. 199.

${ }^{55}$ Carvalho, pp. 68-70.

56 BNE, MS 8980, fol. 330. 
events, together with other documents. For example, he sent portraits of Isabel Cristina of Brunswick-Wolfenbüttel to Barcelona - this princess was one of the principal candidates to marry Archduke Charles in 1705. In fact, they would marry later in 1708 . He also sent a portrait of Archduchess Maria Anna (the future Queen of Portugal) to the court of Lisbon. ${ }^{57}$ Sending such paintings was a common practice and had the objective of letting their would-be spouses, Archduke Charles and Crown Prince John of Portugal respectively, know what their possible future wives looked like. Later on, Sousa Pacheco would order quality campaign tents and other luxuries and send them to Lisbon. However, the court showed its disappointment by advising him not to spend money on such banalities and urged him to acquire another type of products, such as weapons, grain, and horses instead. ${ }^{58}$

On the other hand, he also sent a portrait of the Portuguese Queen to Charles' court in $1709 .{ }^{59}$ It is proof that there was an established direct line of diplomacy connecting Francisco de Sousa Pacheco, the Count of Assumar and the pretender to the throne of Spain.

Moreover, Sousa Pacheco was also in charge of sending some letters and bills of exchange to the Portuguese finance inspector in Catalonia, attached to the letters to the Count of Assumar. In spite of being traditionally viewed as an unsuccessful and low tier diplomat, Sousa Pacheco proficiently dealt with the lack of payment allied troops were suffering, especially the Portuguese, in the Iberian Peninsula. Trying to remedy this, he was successful in managing to provide Joáo Bressane Leyte, the Portuguese finance inspector in Catalonia, with 150,000 florins and 10,000 patacas for the troops' payment through the Cambiaso e Piuma, a credit house in Genoa. ${ }^{60}$ Another 80,000 florins were sent to that same credit house through Francisco de Sousa Pacheco's affairs agent, Alexandre Nunes da Costa, whose father, Jeronimo, was Portugal's affairs agent for many decades in the seventeenth century. ${ }^{61}$ Nonetheless, it was still not enough as many Portuguese chose to end their loyalty

\footnotetext{
${ }^{57}$ Ibid., fol. 13; ibid., fols 306-07v.

${ }^{58}$ Francis, p. 231.

59 BNE, MS 8980, fol. 330.

${ }^{60}$ Ibid., fols 164-65v.

${ }^{61}$ Ibid., fols 181, 189.
} 
and desert, mostly due to poor leadership and lack of payment. The Portuguese generals didn't enforce justice enough, thus leading to a lack of discipline. The English and Dutch, however, still chose to maintain the Portuguese troops as they were the cheapest option, even if they lacked training, payment and command. ${ }^{62}$

\section{Espionage and interception}

The availability of information within the population and the necessity of a continuous flow of news about the military movements and enemy intentions influenced the purposes of intercepting the correspondence of the other side. Francisco de Sousa Pacheco also referred cases of espionage in his letters. Among others, he mentioned a couple of times "letters of France" which informed Francisco de Sousa Pacheco of the situation in Spain, like the withdrawal of the siege of Barcelona in $1705 . .^{63}$ There is no record of who the author of these letters could have been, yet, to a certain extent, it could mean there was some intelligence on Louis XIV's court, providing faster information to The Hague than the letters from the Count of Assumar. ${ }^{64}$ However, these references appear very few times, so they lack the frequency of the much-needed information.

A worrying situation was mentioned often between 1705 and 1706 during the interruption of the mail service going through Genoa, with the war there being considerably intense between the French, the Duchy of Savoy and the Holy Roman Empire. ${ }^{65}$ It was reported that there were packages intercepted by the Allies in Italy, in January 1706, containing letters from cardinal César d'Estrées written in Madrid and France, communicating some turmoil in the court in Madrid and the suspicion about the unlikelihood of Philip V to withdraw to France. ${ }^{66}$ Also, in his letter of 11 June 1706, he mentioned the fact that some French corsairs had intercepted the packet boat that was on

\footnotetext{
${ }^{62}$ Diario Bellico, p. 81.

${ }^{63}$ BNE, MS 8980, fol. 11.

64 Ibid., fol. 254v.

65 Carvalho, p. 68.

66 BNE, MS 8980, fol. 38.
} 
his way from Lisbon to The Hague. Fortunately, the crew made sure to throw the entire mail overbroad into the sea before it ended up in enemy hands. ${ }^{67}$

\section{FINAL REMARKS}

The article provides a brief insight into what looks like an information network all around Europe, where information gathered in The Hague was duly prepared and then relayed to Lisbon and Barcelona. Together with London and Vienna, they compose a network which managed to get information from their territories. Francisco de Sousa Pacheco was one of the few diplomats sending information from Europe to Catalonia at that time, which Charles III used to his interests. João de Almeida Portugal, replied in the same manner, sending information from Barcelona to The Hague, thus to the other allied states. This process, which worked for mutual benefit, placed Portugal in a role of intermediary between Catalonia and the rest of Allies, especially the Maritime Powers - England and the United Provinces. The exchange of letters would have increasing importance in the context of the war, mainly because its information was essential for the political and military decision-making process at higher levels. For that, they needed to organise the themes they wanted to write about in their letters, although it depended much on the amount of information available. The downside of this is essentially the irregularity of the mail, mostly affected by the lack of a sound postal service in the Iberian Peninsula, being the Dutch packet boats and the English escort the only guarantee of a sure arrival of the correspondence. It caused the information to arrive often outdated, possibly caused by some interference laid down by Spain or France. Only after the end of the war, in 1718, some efforts were made to start regulating the mail within Portugal and Spain.

The letters of Francisco de Sousa Pacheco produced tremendous amounts of information, making him an outstanding diplomat in the informative side of his functions. Besides keeping Portugal relevant in the war, he was also a valuable information source for Portugal itself who

${ }^{67}$ Ibid., fol. 65. 
was increasingly being isolated by the Allies. There are some aspects he didn't write about, like, for instance, the poor state of affairs the United Provinces were experiencing in that period. Although he did criticise, from time to time, how little was known about Portugal and Catalonia, it could be concluded that this correspondence was also an underlying propaganda vehicle, where sensitive information was censored out. It could explain why he got modest results in the negotiations with the United Provinces for financial and military support to the allied troops stationed in Catalonia. He did, however, contribute to paying some of the soldiers' wages, especially the Portuguese, but his efforts to achieve the necessary amounts ended up with little success. It could have been also a direct consequence of the financial collapse of the United Provinces caused by this war, considering the rest of the conflicts they previously had against France in the seventeenth century. They had to use most of its resources to defend their own territory and to finance most of the military expeditions and the allied armies in the northern theatre. This situation encouraged soldiers to desert more frequently.

Ultimately, Portugal ended up with an increasing dependency on foreign states support, mainly Great Britain, with whom they maintain the Anglo-Portuguese Alliance since medieval times. This dependency came as a direct consequence of the persistent Portuguese shortage of supplies, together with not being able of either incorporating enough soldiers and competent officers or raising enough capital. Also, vast resources were needed to protect its colonial empire, mainly Brazil. Nevertheless, the need for international recognition and its geopolitical strategies made it crucial for Portugal to participate in the war. It managed to secure alliances which would guarantee the security of its Atlantic colonies and routes. Concurrently, Portugal embarked on an ambitious program of diplomatic representation to the main European courts since the beginning of the war, and both Francisco de Sousa Pacheco and João de Almeida Portugal helped to promote the internationalisation of their of their Kingdom with a significant relevance in the decades to come. 


\section{BIBLIOGRAPHY}

\section{Archival Sources}

Biblioteca Nacional de España

MS 8980 - letters from Francisco de Sousa Pacheco to João de Almeida Portugal, Second Count of Assumar, 1705-1709

\section{Secondary Works}

Albareda, Joaquim, La Guerra de Sucesión en España (1700-1714) (Barcelona: Crítica, 2010)

Belo, André, As Gazetas e os Livros. A Gazeta de Lisboa e a Vulgarização do Impresso em Portugal (1715-1760) (Lisboa: Instituto de Ciências Sociais, 2001)

Cal Martínez, María Rosa, 'La Gaceta de Madrid y la Guerra de Sucesión', Cuadernos Dieciochistas, 3 (2002), 33-56

Cardim, Pedro, “Nem tudo se pode escrever”. Correspondencia diplomática e información "política” en Portugal durante el siglo XVII', Cuadernos de Historia Moderna, 4 (2005), 95-128

, 'Portugal en la guerra por la sucesión de la Monarquía española', in La Guerra de Sucesión en España y la batalla de Almansa: Europa en la encrucijada, coord. by Francisco García González (Madrid: Sílex, 2009), pp. 231-85

Carvalho, João, 'Diplomacia, Guerra y Comunicación. La correspondencia de Francisco de Sousa Pacheco, enviado portugués en La Haya (1703-1709)', unpublished master's thesis (Complutense University of Madrid, 2016)

Cluny, Isabel, 'A Casa de Vilar Maior/ Alegrete e as alianças matrimoniais da dinastia de Bragança', in Casamentos da Familia Real Portuguesa. Diplomacia e cerimonial, vol. 2, cood. by Ana Maria Rodrigues, Manuela Santos Silva and Ana Leal de Faria (Lisbon: Circulo de Leitores, 2017), pp. 49-78

Cózar Gutiérrez, Ramón, 'La participación portuguesa en la Guerra de Sucesión espańola a través de las Relaciones de Sucesos de su Biblioteca Nacional', in La Guerra de Sucesión Española y la opinión pública hispano-británica, ed. by Pedro Losa Serrano (Madrid: Sílex, 2014), pp. 133-70

Diario Bellico. La Guerra de Sucesión en España, de Fra Domingos da Conceição, ed. by Joaquim Albareda, Virginia León Sanz (Alicante: Universidad de Alicante, 2013)

Ettinghausen, Henry, 'Politics and the press in Spain', in The Politics of Information in Early Modern Europe, ed. by Brendan Dooley and Sabrina A. Baron (London: Routledge, 2011), pp. 199-215

Francis, Alan David, The Methuens and Portugal, 1691-1708 (Cambridge: Cambridge University Press, 1966)

Kamen, Henry, The War of the Succession in Spain, 1700-1715 (Bloomington: Weidenfeld and Nicolson, 1969)

Martín Marcos, David, 'A embaixada de D. João de Almeida Portugal, $2^{\circ}$ conde de Assumar, na corte do arquiduque Carlos: Notas diarísticas, percepções e identidade', 
in Repensar a identidade: $O$ mundo ibérico nas margens da crise da consciência europeia, org. by David Martín Marcos, José Maria Iñurritegui and Pedro Cardim (Lisbon: Centro de História d'Aquém e d'Alem Mar, Faculdade de Ciências Sociais e Humanas, Universidade Nova de Lisboa, 2015), pp. 263-84

Schutte, Otto, Repertorium der Nederlandse vertegenwoordigers, residerende in het buitenland: 1584-1810 (The Hague: Martinus Nijhoff, 1983)

João Manuel Oliveira de Carvalho - PhD student and researcher, School of Arts and Humanities of the University of Lisbon; e-mail: joao18@campus.ul.pt 